\title{
Synthesis of some new heterocyclic compounds derived
}

\section{from 2-Chloro-3-formyl quinoline}

\author{
Ala I. Ayoob \& Fatma N. Mohmood \\ Dept. of Chemistry - College of Sciences
}

\section{University of Mosul}

\section{الخلاصة}

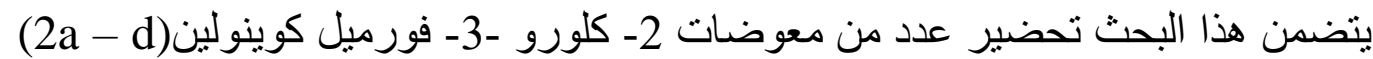

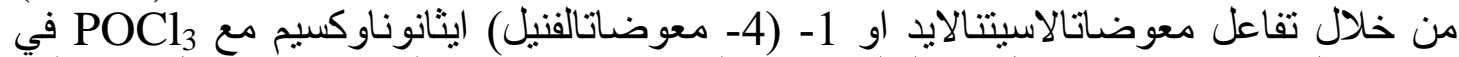

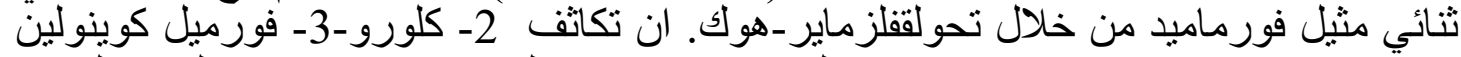

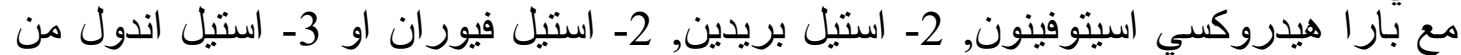

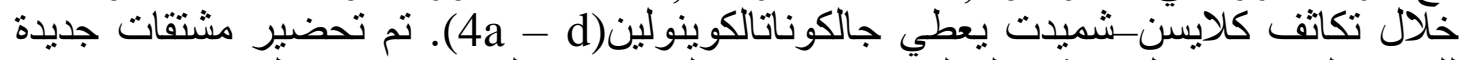

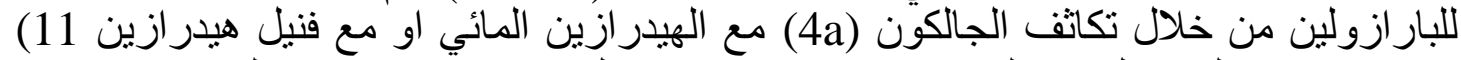

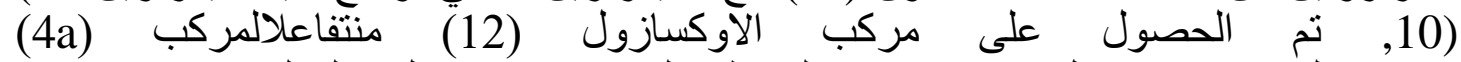

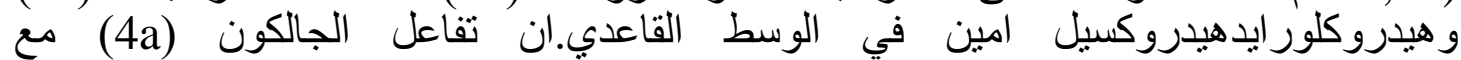

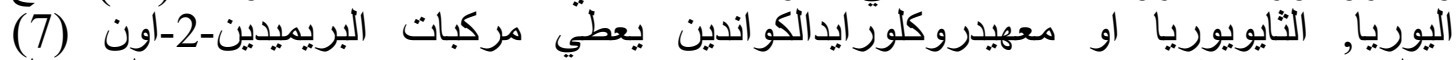

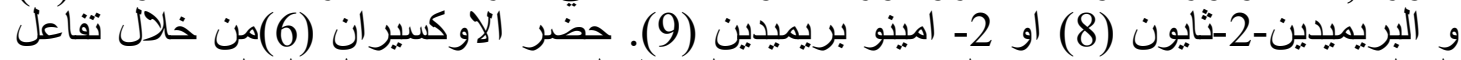

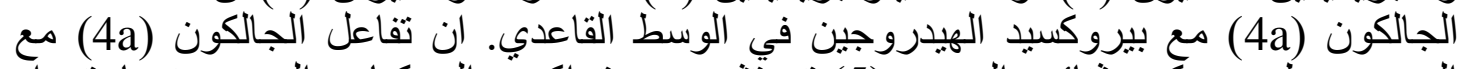

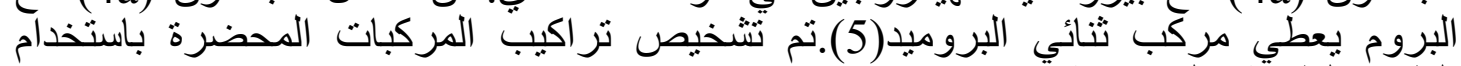
الطرق الطيفية و الفيزياوية.

\section{ABSTRACT}

In this paper the Synthesis of some substituted 2-Chloro-3-formyl quinoline $(2 \mathrm{a}-\mathrm{d})$ by treating various substituted acetanilide or 1-(4-substituted phenyl) ethanone oxime with $\mathrm{POCl}_{3}$ in dimethyl formamide. It proceeds through Vilsmeier - Haack cyclization. The condensation of 2-chloro-3-formylquinoline with $p$ Hydroxyacetophenone, 2-acetyl pyridine, 2-acetyl furan or 3-acetyl indole via Claisene- Schmiatcondensations gives quinolinylchalcone (4a - d). Newpyrazoline derivatives were synthesized by condensing the appropriate chalcone (4a) with hydrazine hydrate or phenylhydrazine (10 - 11). Oxazole (12) is reported from compound (4a) and hydroxyl amine hydrochloride is in basic medium. The reaction of chalcone (4a) with urea, thiourea or quinidine hydrochloride gives pyrimidine-2-one (7), pyrimidine-2-thiol (8) or 2- amino pyrimidine (9) respectively.Oxirane (6) prepared from reaction of chalcone (4a) with hydrogen peroxide in basic medium. The reaction of chalcone (4a) with bromine gives dibromide (5). The structures of synthesized compounds were confirmed by spectral and physical methods.

Presented at the second conference on Chemistry, University of Mosul, college of Education, 17-18 Novamber-2013. 


\section{INTRODUCTION}

Quinoline, also known as L-azanaphthalene, 1-benzaine or benzo(b)pyridine is an aromatic nitrogen compound characterized by a double ring structure contain a benzene fused pyridine at two adjacent carbon. Quinoline family compounds are widely used as a parent compound to make drug especially anti-malarial [1], anti-inflammatory [2,3], anti-bacterial [3,4,5], anti-fungal [6], anti-microbial agent [7], antitumor [8], analgesic [9]. The plant family have been known to be the rich source of quinoline alkaloids [10], pyranoquinoline alkaloids gained importance due to their several pharmacological activities like anticoagulant [11]. Several quinoline derivatives isolated from natural resources or prepared synthetically are significant with respect to medicinal chemistry and biomedical use. Indeed quinoline derivatives are some of the oldest compounds which have been utilized for the treatment of a variety of disease. The bark of the cinchona plant containing quinine was utilized to treat palpitations [12]. There are many methods available for functionalized quinolines the Vilsmeier approach is found to be among the most efficient for achieving useful transformations and hetero annulations, in fact 2-chloro-3-formyl quinoline the primary intermediate, is a good starting material for the preparation of different quinoline derivatives.

\section{MATERIALS AND METHODS}

Melting point were recorded on electrothermal SMP30 melting point apparatus and are uncorrected, IR spectra were recorded on infrared spectrophotometer model tensor, Bruker Co. Germany by using $\mathrm{KBr}$ discs. ${ }^{13} \mathrm{C},{ }^{1} \mathrm{H}$ NMR spectra were recorded on a JEol 400MH, using Tetramethyl saline (TMS) as internal standard.

\section{EXPERIMENTAL}

The starting material, substituted acetanilide $\left(\mathrm{I}_{\mathrm{a}}, \mathrm{I}_{\mathrm{b}}\right)$ was readily prepared from the reaction of corresponding anilines with acetic anhydride in aqueous medium [13].

\section{General procedure for the Synthesis of substituted 2-Chloro-3-formyl} quinoline (2a and 2b) [14].

To a solution of $\mathrm{I}_{\mathrm{a}}$ and $\mathrm{I}_{\mathrm{b}}(5$ mmoles) in dry DMF (15 mmoles) at $(0-15){ }^{\circ} \mathrm{C}$ with stirring $\mathrm{POCl}_{3}$ (35 mmoles) was added drop wise. The mixture stirred at $\left(80-90^{\circ} \mathrm{C}\right)$ for $16 \mathrm{hrs}$. The mixture was poured into crushed ice, stirred for $1 \mathrm{hr}$. and the resulting solid filtered, washed well with water and dried; the compounds were purified by recrystallizationfrom ethyl acetate. The melting point was $\left(148-151^{\circ} \mathrm{C}\right)$ and $\left(179-181^{\circ} \mathrm{C}\right)$ with $36 \%$ yield. The IR spectra and physical properties are listed in Table 1. (Scheme 1). 


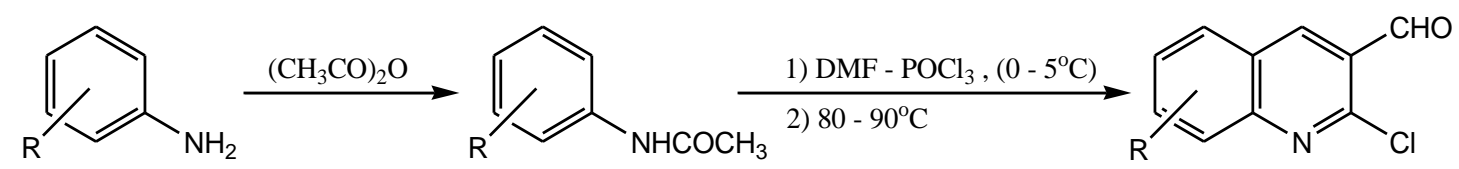

(1)

(2)

Scheme 1: Synthesis of 2-Chloro-3-formyl quinoline $(2 a-b)$
(1) $\mathbf{R}$
A $\mathrm{H}$
b $\quad m-\mathrm{CH}_{3}$

(2) $\quad \mathbf{R} \quad \mathbf{m} \cdot{ }^{\circ} \mathbf{C}$

a $\mathrm{H} \quad 148-151$

b $7-\mathrm{CH}_{3} \quad 179-181$

General procedure for the Synthesis of 1-(4-substituted phenyl) ethanone oxime $(3 \mathbf{a}-\mathbf{d})$ :

The 1-(4-substituted phenyl) ethanone oximes were synthesized from different substituted acetophenone $(0.1 \mathrm{~mol})$, hydroxyl amine hydrochloride $(0.12 \mathrm{~mol})$ and sodium acetate $(0.12 \mathrm{~mol})$ using method reported by Chon et al. [14].

General procedure for the Synthesis of 2-Chloro-3-formyl quinoline from oxime $(2 \mathrm{a}-\mathrm{d})[1,3]$ :

To dry DMF $(0.15 \mathrm{~mol})$ cooled to $\left(0-5^{\circ} \mathrm{C}\right), \mathrm{POCl}_{3}(0.35 \mathrm{~mol})$ was added drop wise under stirring, and then the respective oxime $(0.05 \mathrm{~mol})$ was added portion-wise. The reaction mixture was heated at $\left(80-90^{\circ} \mathrm{C}\right)$ for $12 \mathrm{hrs}$. . It was then poured into ice water $(300 \mathrm{~mL})$ and stirred for $1 \mathrm{hr}$. The substituted 2-Chloro-3-formyl quinoline was filtered and recrystallized from ethyl acetate. The IR spectra and physical properties are listed in Table 1. (Scheme 2).<smiles>[R]c1ccc(C(C)=O)cc1</smiles>

Scheme 2: Synthesis of 2-Chloro-3-formyl quinoline from oxime (2a-d)

(3)

(3)

a $-\mathrm{H}$

b $\quad 4-\mathrm{NH}_{2}$

c $4-\mathrm{OH}$

d $2-\mathrm{OH}, 4-\mathrm{OCH}_{3}$
(2)

a $\mathrm{H}$

b $6-\mathrm{NH}_{2}$

c $\quad 7-\mathrm{OH}$

d $5-\mathrm{OH}, 7-\mathrm{OCH}_{3}$ m.p ${ }^{\circ} \mathbf{C}$

147-152

216-220

140-142

144-146 


\section{General procedure for Synthesis of Quinolinyle chalcones $(4 a-d)$} [15]:

2-Chloro-3-formyl quinoline $(0.01 \mathrm{~mol})$ was added to an ethanolic $(15 \mathrm{~mL})$ solution of $p$-Hydroxy acetophenone, 2-acetyl pyridine, 2-acetyl furan or 3-acetyl indole $(0.01 \mathrm{~mol})$.

To the above reactionmixture, aqueous $\mathrm{NaOH}(40 \%, 0.03 \mathrm{~mol}$, $3 \mathrm{~mL}$ ) was added drop-wise with stirring. The reaction mixture was kept overnight, then acidified with cold dilute $\mathrm{HCl}$, and the resulting solid filtered, washed well with water and dried. The IR spectra and physical properties are listed in Table 1. (Scheme 3).

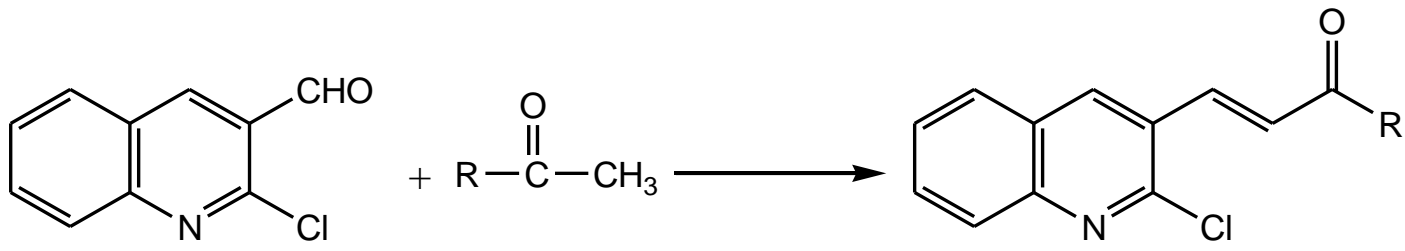

Scheme 3: Synthesis of quinolinyle chalcone $(4 a-d)$

$4 \mathbf{a}$

(E)-3-(2-Chloroquinolin-3-yl)-1-(4-hydroxy

phenyl)prop-2-en-1-one

4b

(E)-3-(2-Chloroquinolin-3-yl)-1-(pyridine-3-yl)prop-2en-1-one

$4 c$

(E)-3-(2-Chloroquinolin-3-yl)-1-(furan-2-yl)prop-2en-1-one

4d

(E)-3-(2-Chloroquinolin-3-yl)-1-(1H-indol-3-yl)prop2-en-1-one<smiles>[R]c1ccc(O)cc1</smiles>

m.p ${ }^{\circ} \mathrm{C}$

185-187<smiles>CC(=O)c1ccccn1</smiles>

$278-280 d$<smiles>CC(=O)c1ccco1</smiles>

$160-162$<smiles>CC(=O)c1c[nH]c2ccccc12</smiles>

3-(2-Chloroquinolin-3-yl)-1-(4-hydroxy phenyl)-2,3-dibromo-1-one (5):

To a stirred mixture of compound (4a) $\left(5 \times 10^{-4} \mathrm{~mol}, 0.36 \mathrm{gm}\right.$.)in $15 \mathrm{~mL}$ ethanol was slowly added $(1 \mathrm{~mL})$ of bromine. The reaction mixture was kept overnight at room temperature. The precipitate formed was collected, washed with water. The melting point was $192-195^{\circ} \mathrm{C}$. The physical properties are listed in Table 1.

\section{3-(2-Chloroquinolin-3-yl)-1-(4-hydroxyphenyl)-2,3-epoxy-1-} propanone $(6)[16]$ :

To solution of compound $4 \mathrm{a}(0.5 \mathrm{~mol}, 0.86 \mathrm{gm})$ in $25 \mathrm{~mL}$ of methanol at $30^{\circ} \mathrm{C}$, was added $(1 \mathrm{~mL})$ of $30 \%$ hydrogen peroxide, then $(0.5 \mathrm{~mL})$ of $16 \%$ Sodium hydroxide was added drop by drop with stirring 
for $(3 h r$.$) . The mixture was cooled and left overnight at room$ temperature; precipitate was formed, recrystallized from ethanol. The melting point was $\left(121-124^{\circ} \mathrm{C}\right)$. The physical properties are listed in Table 1.

\section{4-(2-Chloroquinolin-3-yl)-6-(4-hydroxyphenyl)-3,4-dihydropyrimidine- 2(1H)-one(7) [17]:}

A solution of compound $4 \mathrm{a}(0.02 \mathrm{~mol}, 0.61 \mathrm{gm})$ in $15 \mathrm{~mL}$ ethanol was added to solution of Sodium ethoxide and urea (0.02mol, $0.34 \mathrm{gm})$. The reaction mixture was heated under reflux for $2 \mathrm{hrs}$. , the mixture was cooled and diluted with water and left overnight. The resulting product was filtered off, washed with $20 \mathrm{~mL}$ of a mixture of water / ethanol (1:1 $\mathrm{v} / \mathrm{v})$. The melting point was $\left(154-156^{\circ} \mathrm{C}\right)$. The physical properties are listed in Table 1.

\section{4-(2-Chloroquinolin-3-yl)-6-(4-hydroxyphenyl)-3,4-dihydropyrimidine- 2(1H)-thione (8) [17]:}

Compound $4 \mathrm{a}(0.02 \mathrm{~mol}, 0.61 \mathrm{gm})$ was added to Sodium ethoxide solution $(0.1 \mathrm{gm}$ of Sodium metal in $20 \mathrm{~mL}$ of absolute ethanol). Then thiourea $(0.02 \mathrm{~mol}, 0.38 \mathrm{gm})$ was added. The reaction mixture was refluxed for $4 \mathrm{hrs}$. The precipitate which separated on cooling washed with ethanol. The melting point was $\left(175-177^{\circ} \mathrm{C}\right)$. The physical properties are listed in Table 1.

\section{2-Amino-4-(2-chloroquinolin-3-yl)-6-(4-hydroxyphenyl)-3,4-dihydro pyrimidine (9) [18]:}

In a $100 \mathrm{~mL}$ two necked round bottomed flask equipped with a dropping funnel which charged with a solution of Sodium hydroxide $(0.4 \mathrm{gm}$ in $5 \mathrm{~mL}$ of water), a mixture of $4 \mathrm{a}(0.0048 \mathrm{~mol}, 0.58 \mathrm{gm})$ and quainidine hydrochloride $(0.0048 \mathrm{~mol}, 0.86 \mathrm{gm})$, in $20 \mathrm{~mL}$ of ethanol was refluxed while the solution of Sodium hydroxide was added drop by drop with stirring during $2 \mathrm{hrs}$. . The mixture was reflux for $10 \mathrm{hrs}$. . Let the mixture at room temperature then diluted with water and left overnight, precipitate was formed washed with $20 \mathrm{~mL}$ of a mixture of water/ethanol $(1: 1 \mathrm{v} / \mathrm{v})$ then recrystallized from benzene to give compound (9).The melting point was $\left(194-196^{\circ} \mathrm{C}\right)$. The physical properties are listed in Table 1. 
3-(2-Chloroquinolin-3-yl)-5-(4-hydroxyphenyl)-2,3dihydropyrazoline(10)[19]:

A mixture of compound $4 \mathrm{a}\left(5 \times 10^{-3} \mathrm{~mol}, 1 \mathrm{gm}\right)$ and hydrazine hydrate $\left(5 \times 10^{-3} \mathrm{~mol}, 2 \mathrm{~mL}\right)$ in $20 \mathrm{~mL}$ ethanol was refluxed for $4 \mathrm{hrs}$. The reaction mixture was concentrated to half under vacuum, then left to cool, the precipitate which separated was collected, washed with water and recrystallized from ethanol.The melting point was $\left(186-188^{\circ} \mathrm{C}\right)$. The physical properties are listed in Table 1.

\section{1-Phenyl-2-(2-chloroquinolin-3-yl)-4-(4-hydroxyphenyl)-1,2- dihydropyrazoline(11)[19]:}

A mixture of compound $4 \mathrm{a}\left(25 \times 10^{-4} \mathrm{~mol}, 0.61 \mathrm{gm}\right)$ and phenyl hydrazine $\left(25 \times 10^{-4} \mathrm{~mol}, 0.27 \mathrm{gm}\right)$ in ethanol was refluxed for $24 h r s$. . The reaction mixture was concentrated to half under vacuum. The precipitate which separated on cooling was recrystallized from ethanol.The melting point was $\left(192-195^{\circ} \mathrm{C}\right)$. The physical properties are listed in Table 1.

3-(2-Chloroquinolin-3-yl)-5-(4-hydroxyphenyl)-4,5-dihydroOxazole(12)[20]: A solution of compound $4 \mathrm{a}\left(5.2 \times 10^{-3} \mathrm{~mol}, 0.63 \mathrm{gm}\right)$ in $10 \mathrm{~mL}$ ethanol was added to the mixture of hydroxyl amine hydrochloride $(0.014 \mathrm{~mol}, 2.30 \mathrm{gm})$ and Sodium hydroxide $(10 \%)$. The reaction mixture was refluxed for $1 \mathrm{hr}$. in water bath. The precipitate which separated on cooling was washed with cold water and recrystallized from ethanol.The melting point was $\left(154-159^{\circ} \mathrm{C}\right)$. The physical properties are listed in Table 1.

\section{RESULTS AND DISCUSSION}

Although many routes have been developed for functionalized quinoline [21, 22, and 23] the Vilsmeier approach is found to be among the most efficient for achieving useful transformation and hetero annulation. Thus in the communication is reported the Synthesis of substituted2-Chloro-3-formylquinolines from the reaction of substituted acetanilide with Vilsmeier reagent and transformation of2-Chloro and 3formyl group into different functionalities. The Vilsmeier cyclization of substituted acetanilides was carried out by adding $\mathrm{POCl}_{3}$ to the substrate in $\mathrm{DMF}$ at $0-5^{\circ} \mathrm{C}$ followed by heating to $90^{\circ} \mathrm{C}$ to afford2-Chloro-3formylquinoline. The mechanism of reaction work according to the Scheme 4. 
<smiles>C[C@@H](CCCOC(=O)N(C)C)C(=O)OP(=O)(Cl)Cl</smiles><smiles>CN(C)[C@H](Cl)[C@H]1CC[N+](C)(C)C1</smiles>

Scheme 4: The mechanism of Vilsmeier - Haack reaction

Another method to prepared substituted 2-Chloro-3formylquinolines from the reaction of substituted phenyl ethanone oxime with $\mathrm{POCl}_{3}$ in the presence of DMF using the Vilsmeier - Haack reaction method [24], and the mechanism of formation of phenyl ethanone oxime according to Scheme 5.
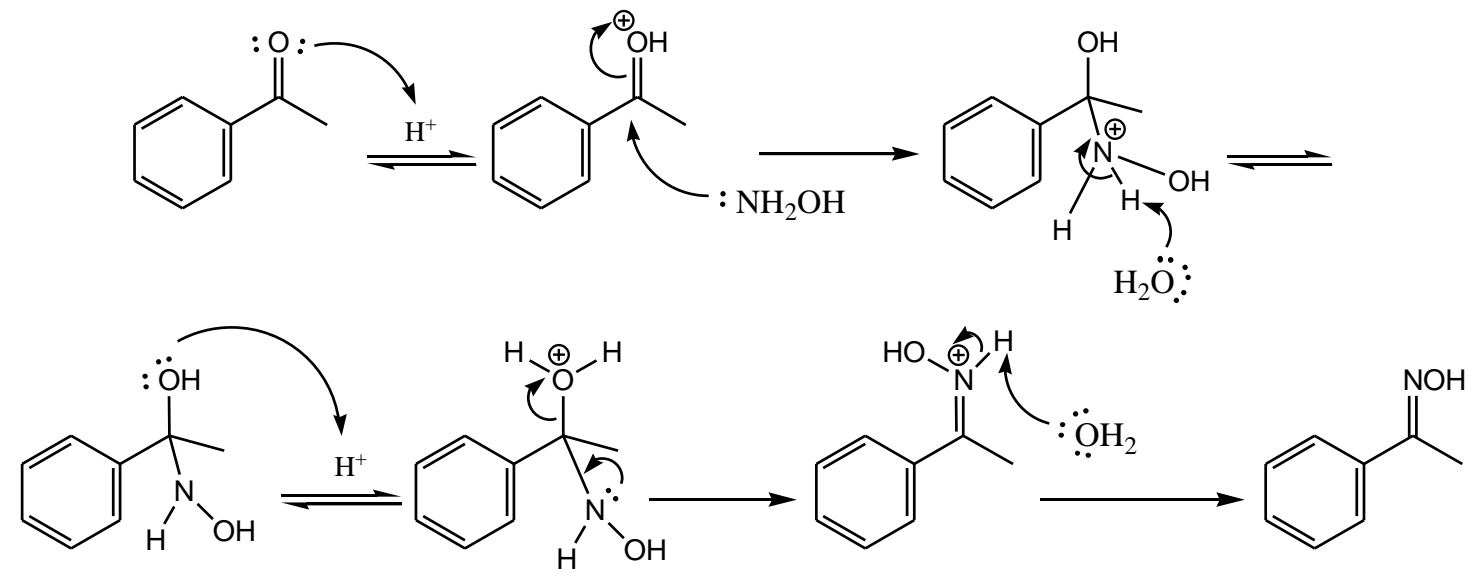

Scheme 5: The mechanism of oxime formation

Structures of the synthesized compounds were elucidated by mean of physical and spectral data (Table 1). The IR spectra of compounds $(2 \mathrm{a}-\mathrm{d})$ showed characteristic absorption band in the reign $\left(1664-1686 \mathrm{~cm}^{-}\right.$ ${ }^{1}$ ) for $\mathrm{C}=\mathrm{O}$ function and at reign $\left(1552-1571 \mathrm{~cm}^{-1}\right)$ for $\mathrm{C}=\mathrm{N}$ function and at $\left(780-756 \mathrm{~cm}^{-1}\right)$ for $\mathrm{C}-$ Clfunction (Fig. 1). The ${ }^{1} \mathrm{H}$ NMR spectra for compound (2a) in $\mathrm{CDCl}_{3}$ (Fig.2, Table 2) showed significant peak as the following triplet at 7.61-7.68 for $\mathbf{H - 7}$, triplet at 7.84-7.91 for $\mathbf{H - 6}$, doublet at 7.97-8.02 for $\mathbf{H - 8}$, doublet at 8.06-8.10 for $\mathbf{H - 5}$, singlet at 8.73 for $\mathbf{H - 4}$ and singlet at 10.5 for aldehydic proton. The ${ }^{13} \mathrm{C}$ NMR spectra of this compound (Fig.3, Table 2) showed a carbonyl peak at 189.2. 
Compounds (4a-d) have been prepared via Claisen-Schmidt condensation in ethanolic solution of 2-Chloro-3-formyl quinoline with $p$-Hydroxy acetophenone, 2-acetyl pyridine, 2-acetyl furan and 3-acetyl indole. The IR spectra of these compounds showed a strong absorption bands observed at reign $\left(1642-1695 \mathrm{~cm}^{-1}\right)$ were attributable to the carbonyl, $(\mathrm{C}=\mathrm{O})$, at $\left(1579-1615 \mathrm{~cm}^{-1}\right)$ suggested the presence of $\mathrm{C}=\mathrm{C}$ group. In addition, bands were observed at (1560-1581 $\left.\mathrm{cm}^{-1}\right)$ and at 747 $\mathrm{cm}^{-1}$ corresponding to $\mathrm{C}=\mathrm{N}$ and $\mathrm{C}-\mathrm{Cl}$ groups (Table 1 ). The ${ }^{1} \mathrm{H}$ NMR spectra for compound (4c) in $\mathrm{CDCl}_{3}$ (Fig. 4 and 5) (Table 2) showed significant peak as the following, singlet at 8.17 for $\mathbf{H}-4$, doublet at 8.017.99 for $\mathbf{H - 5}$, doublet at 7.77-7.75 for $\mathbf{H}_{\beta}$, triplet at 7.67-7.53 forH-6, multiplet at 7.53-7.51 for $\mathbf{H - 8}$, multiplet at 7.25-7.22 for $\mathbf{C}_{7}$ and $\mathbf{H}_{\boldsymbol{a}}$, multiplet at 6.504-6.500, doublet at 6.32 and doublet at 4.54-4.52 for $\mathbf{H}_{2}$, $\mathbf{H}_{3}$ and $\mathbf{H}_{4}$ respectively for furan ring. The ${ }^{13} \mathrm{C}$ NMR spectra of this compound (Fig. 6, Table 2) showed a carbonyl peak at 186.9. The compound (5) was prepared from reaction of chalcone (4a) with bromine (Scheme 6). The IR spectral data for the compound exhibit an absence of absorption at about $1601 \mathrm{~cm}^{-1}$ for $\mathrm{C}=\mathrm{C}$ and a presence of a strong absorption at about1698 $\mathrm{cm}^{-1}$ which attributed to carbonyl group. The reaction between compound (4a) and $30 \%$ hydrogen peroxide in basic medium can formed compound (6) (Scheme 6). The IR spectral data exhibit an absence of absorption at about $1601 \mathrm{~cm}^{-1}$ for $\mathrm{C}=\mathrm{C}$ and a presence of a strong absorption at $1702 \mathrm{~cm}^{-1}$ attributed to the $\mathrm{C}=\mathrm{O}$ group. A medium absorption at $1584 \mathrm{~cm}^{-1}$ for aromatic $\mathrm{C}=\mathrm{N}$, and absorption at $1029 \mathrm{~cm}^{-1}$ duo toC-O-C of epoxide ring. The ${ }^{1} \mathrm{H}$ NMR spectra for compound (6) in $\mathrm{CDCl}_{3}$ (Fig.7 and 8) (Table 2) showed significant peak as the following, singlet at 8.68 for $\mathbf{H}-\mathbf{4}$, doublet at 8.11-8.13 for $\mathbf{H - 5}$, triplet at 7.88-7.90 for $\mathbf{H - 6}$, triplet at 7.41-7.43 for $\mathbf{H - 7}$, doublet at 7.697.71 for $\mathbf{H - 8}$, multiplet at 7.06-7.41 for Ar-H, singlet at 6.53 for phenolic proton and multipletat 4.33 and doublet at 4.993-4.997 for $\mathbf{H - 2}$ andH-3 for epoxide ring.The ${ }^{13} \mathrm{CNMR}$ spectra for this compound (Fig.9, Table 2) in $\mathrm{CDCl}_{3}$ showed a carbonyl peak at 193.53. The pyrimidine compound (7) was synthesized from reaction of chalcone (4a) and urea in Sodium ethoxide solution (Scheme 6). The IR spectra data for compound showed the absence of two important absorptions, the first is absorption of carbonyl group at $1673 \mathrm{~cm}^{-1}$ and the other is the absorption of olefinic double bond at $1601 \mathrm{~cm}^{-1}$. A strong absorption at $1686 \mathrm{~cm}^{-1}$ due to carbonyl group in the pyrimidine ring, a medium absorption at $1586 \mathrm{~cm}^{-1}$ and $1477 \mathrm{~cm}^{-1}$ for $\mathrm{C}=\mathrm{N}$ and $\mathrm{C}=\mathrm{C}$ corresponding to aromatic system. The reaction of compound (4a) with thiourea can formed compound (8). The IR spectral data showed the absence of absorption at $1673 \mathrm{~cm}^{-1}$ and at $1607 \mathrm{~cm}^{-1}$ for $\mathrm{C}=\mathrm{O}$ group and olefinic double bond respectively. New absorption appeared at $1155 \mathrm{~cm}^{-1}$ for $\mathrm{C}=\mathrm{S}$ group in pyrimidine ring, a 
medium absorption at $1558 \mathrm{~cm}^{-1}$ and at $1448 \mathrm{~cm}^{-1}$ for $\mathrm{C}=\mathrm{N}$ and $\mathrm{C}=\mathrm{C}$ corresponding to aromatic system. The IR spectral data for compound (9) showed the disappearance of absorption at $1673 \mathrm{~cm}^{-1}$ and $1601 \mathrm{~cm}^{-1}$ corresponding to $\mathrm{C}=\mathrm{O}$ group and for olefinic double bond, and exhibited absorption at $3487 \mathrm{~cm}^{-1}$ for $\mathrm{N}-\mathrm{H}$ group. The reaction of chalcone (4a) with hydrazine hydrate and phenyl hydrazine can formed pyrazoline (10, 11). The IR spectra of these compounds (Table 1) showed the disappearance of absorption of $\mathrm{C}=\mathrm{O}$ group and olefinic double bond and exhibited absorption at $3359 \mathrm{~cm}^{-1}$ for $\mathrm{N}-\mathrm{H}$ group. And absorption appeared at $1577 \mathrm{~cm}^{-1}$ and $754 \mathrm{~cm}^{-1}$ for $\mathrm{C}=\mathrm{N}$ and $\mathrm{C}-\mathrm{Cl}$ group. The reaction of chalcone (4a) with hydroxylamine hydrochloride can form Oxazole (12). The IR spectral data (Table 1) showed the disappearance of absorption of carbonyl group at $1673 \mathrm{~cm}^{-1}$ and absorption at $1601 \mathrm{~cm}^{-1}$ for olefinic double bond (Table 1).

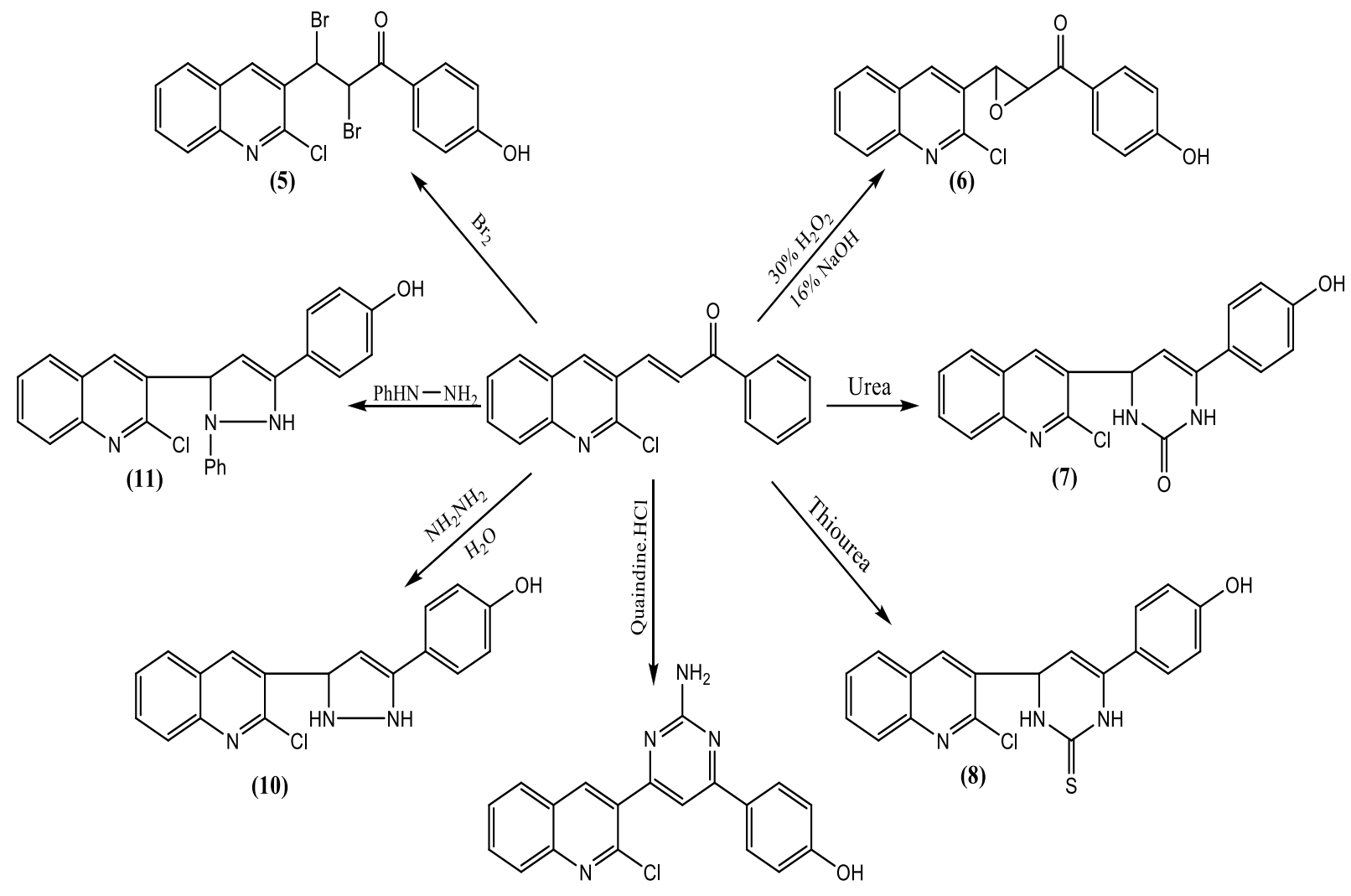

(9)

Scheme 6: Synthesis of chalcone derivatives (5-12) 

Synthesis of some new heterocyclic compounds derived from 2-Chloro ....

Table 1: Physical and IR spectral data of compounds (1-12)

\begin{tabular}{|c|c|c|c|c|c|c|c|c|c|c|c|c|}
\hline \multirow{2}{*}{$\begin{array}{l}\text { Com } \\
\text {. No }\end{array}$} & \multirow{2}{*}{$\begin{array}{c}\text { m.p } \\
{ }^{\circ} \mathrm{C}\end{array}$} & \multirow{2}{*}{$\begin{array}{c}\% \\
\text { yield }\end{array}$} & \multirow{2}{*}{ Formula } & \multicolumn{9}{|c|}{ IR data $\left(\mathrm{cm}^{-1}\right)$} \\
\hline & & & & $\mathrm{C}=\mathrm{O}$ & $\begin{array}{c}\mathrm{C}=\mathrm{C} \\
\text { olefinic }\end{array}$ & $\mathrm{OH}$ & $\mathrm{C}=\mathrm{N}$ & $\begin{array}{c}\mathrm{C}=\mathrm{C} \\
\text { aromatic }\end{array}$ & $\mathrm{N}-\mathrm{H}$ & $\mathrm{C}-\mathrm{Cl}$ & $\mathrm{C}-\mathrm{O}-\mathrm{C}$ & $\mathrm{C}=\mathrm{S}$ \\
\hline $2 a$ & $147-152$ & 36 & $\mathrm{C}_{10} \mathrm{H}_{6} \mathrm{NOCl}$ & 1686 & --- & --- & 1562 & 1470 & --- & 746 & --- & --- \\
\hline $2 b$ & $216-220$ & 13 & $\mathrm{C}_{10} \mathrm{H}_{8} \mathrm{~N}_{2} \mathrm{OCl}$ & 1664 & --- & --- & 1571 & 1491 & 3421 & 756 & --- & --- \\
\hline $2 \mathrm{c}$ & $140-142$ & 55 & $\mathrm{C}_{11} \mathrm{H}_{9} \mathrm{NOCl}$ & 1680 & --- & --- & 1552 & 1490 & --- & 780 & --- & --- \\
\hline $2 \mathrm{~d}$ & $144-146$ & 50 & $\mathrm{C}_{11} \mathrm{H}_{8} \mathrm{O}_{2} \mathrm{NCl}$ & 1685 & --- & 3335 & 1562 & 1495 & --- & 760 & --- & --- \\
\hline $3 a$ & $60-63$ & 47 & $\mathrm{C}_{8} \mathrm{H}_{9} \mathrm{NO}$ & --- & --- & 3238 & 1542 & 1496 & --- & --- & --- & --- \\
\hline $3 b$ & $150-153$ & 80 & $\mathrm{C}_{8} \mathrm{H}_{10} \mathrm{~N}_{2} \mathrm{O}$ & --- & --- & 3354 & 1577 & 1492 & 3295 & --- & --- & --- \\
\hline $3 d$ & $144-146$ & 92 & $\mathrm{C}_{8} \mathrm{H}_{9} \mathrm{O}_{2} \mathrm{~N}$ & --- & --- & 3334 & 1496 & 1496 & 3319 & --- & $\begin{array}{l}-- \\
\end{array}$ & --- \\
\hline $3 c$ & $42-45$ & 52 & $\mathrm{C}_{9} \mathrm{H}_{11} \mathrm{O}_{3} \mathrm{~N}$ & --- & --- & --- & --- & --- & --- & --- & --- & --- \\
\hline $4 a$ & $185-187$ & 53 & $\mathrm{C}_{18} \mathrm{H}_{14} \mathrm{NO}_{2} \mathrm{Cl}$ & 1673 & 1601 & 3444 & 1561 & 1469 & --- & 747 & --- & --- \\
\hline $4 \mathrm{~b}$ & $278-280$ & 77 & $\mathrm{C}_{17} \mathrm{H}_{14} \mathrm{~N}_{2} \mathrm{OCl}$ & 1695 & 1618 & --- & 1587 & 1490 & --- & 749 & --- & $-\overline{--}^{--}$ \\
\hline $4 \mathrm{c}$ & $160-162$ & 92 & $\mathrm{C}_{16} \mathrm{H}_{12} \mathrm{NO}_{2} \mathrm{Cl}$ & 1666 & 1593 & --- & 1562 & 1467 & --- & 750 & --- & --- \\
\hline $4 d$ & $254-256$ & 73 & $\mathrm{C}_{20} \mathrm{H}_{12} \mathrm{~N}_{2} \mathrm{OCl}$ & 1642 & 1616 & --- & 1541 & 1480 & --- & 741 & --- & --- \\
\hline 5 & $192-195$ & 57 & $\mathrm{C}_{17} \mathrm{H}_{12} \mathrm{NOBr}_{2} \mathrm{Cl}$ & 1698 & --- & 3354 & 1562 & 1466 & --- & 784 & --- & --- \\
\hline 6 & $121-124$ & 94 & $\mathrm{C}_{18} \mathrm{H}_{12} \mathrm{NO}_{3} \mathrm{Cl}$ & 1702 & --- & 3384 & 1584 & 1480 & --- & 750 & 1029 & --- \\
\hline 7 & $154-156$ & 80 & $\mathrm{C}_{19} \mathrm{H}_{13} \mathrm{~N}_{3} \mathrm{O}_{2} \mathrm{Cl}$ & 1686 & 1586 & 3420 & 1586 & 1473 & 3420 & 750 & --- & --- \\
\hline 8 & $175-177$ & 43 & $\mathrm{C}_{19} \mathrm{H}_{13} \mathrm{~N}_{3} \mathrm{OClS}$ & --- & --- & 3386 & 1558 & 1447 & 3359 & 754 & --- & 1155 \\
\hline 9 & 194-196 & 84 & $\mathrm{C}_{19} \mathrm{H}_{13} \mathrm{~N}_{4} \mathrm{OCl}$ & --- & --- & 3487 & 1572 & 1488 & 3410 & 758 & --- & --- \\
\hline 10 & 186-188 & 66 & $\mathrm{C}_{18} \mathrm{H}_{13} \mathrm{~N}_{3} \mathrm{OCl}$ & --- & --- & 3433 & 1577 & 1489 & 3359 & 754 & --- & --- \\
\hline 11 & $192-195$ & 34 & $\mathrm{C}_{24} \mathrm{H}_{17} \mathrm{~N}_{3} \mathrm{OCl}$ & --- & --- & 3456 & 1576 & 1498 & --- & 746 & --- & --- \\
\hline 12 & 154-159 & 76 & $\mathrm{C}_{17} \mathrm{H}_{13} \mathrm{~N}_{2} \mathrm{O}_{2} \mathrm{Cl}$ & --- & --- & 3300 & 1586 & 1474 & --- & 756 & --- & $-\overline{--}$ \\
\hline
\end{tabular}

Table $2:{ }^{13} \mathrm{C},{ }^{1} \mathrm{H}$ NMR spectral data of compounds (2a, 4c, 6 )

\begin{tabular}{|c|c|c|}
\hline $\begin{array}{l}\text { Comp. } \\
\text { No. }\end{array}$ & $\begin{array}{c}{ }^{1} \mathrm{H} \text { NMR } \\
\text { Chemical shift }\left(\mathrm{CDCl}_{3}, \delta, \text { ppm) }\right.\end{array}$ & ${ }^{13} \mathrm{C} \mathrm{NMR}\left(\mathrm{CDCl}_{3}\right)$ \\
\hline $\mathbf{2 a}$ & $\begin{array}{c}\left.\text { 7.61-7.65(1H,t, } \mathrm{C}_{7}\right), 7.84-7.91\left(1 \mathrm{H}, \mathrm{t}, \mathrm{C}_{6}\right), 7.95- \\
8.00(1 \mathrm{H}, \mathrm{d}, \mathrm{C} 8), 8.04-8.08\left(1 \mathrm{H}, \mathrm{d}, \mathrm{C}_{5}\right), 8.73- \\
8.76\left(1 \mathrm{H}, \mathrm{s}, \mathrm{C}_{4}\right), 10.5(\mathrm{H}, \mathrm{S}, \mathrm{HC}=\mathrm{O})\end{array}$ & $\begin{array}{c}126.46\left(\mathrm{C}_{3}\right), 126.62\left(\mathrm{C}_{6}\right), 128.23 \\
\left(\mathrm{C}_{8}\right), 128.64\left(\mathrm{C}_{5}\right), 129.81\left(\mathrm{C}_{9}\right), \\
133.70\left(\mathrm{C}_{7}\right), 140.39\left(\mathrm{C}_{4}\right), 149.67 \\
\left(\mathrm{C}_{10}\right), 150.19\left(\mathrm{C}_{2}\right), 189.20(\mathrm{C}=\mathrm{O}) .\end{array}$ \\
\hline $4 c$ & $\begin{array}{c}\left.\text { 8.17(1H,s, } \mathrm{C}_{4}\right), 7,99-8.01\left(1 \mathrm{H}, \mathrm{d}, \mathrm{C}_{5}\right), 7.75- \\
7.77\left(1 \mathrm{H}, \mathrm{d}, \mathrm{H}_{\beta}\right), 7.53-7.67\left(1 \mathrm{H}, \mathrm{t}, \mathrm{C}_{6}\right), 7.518- \\
7.539\left(1 \mathrm{H}, \mathrm{m}, \mathrm{C}_{8}\right), 7.25-7.32\left(1 \mathrm{H}, \mathrm{m}, \mathrm{H}_{\alpha}\right), \\
6.500-6.509\left(1 \mathrm{H}, \mathrm{m}_{2} \dot{C}_{2 \text { furan }}\right), 6.32 \\
\left(1 \mathrm{H}, \mathrm{d}, \dot{C}_{3 \text { furan }}\right), 4.527-7.544\left(1 \mathrm{H}, \mathrm{d}, \dot{C}_{4 \text { furan }}\right) .\end{array}$ & $\begin{array}{c}112\left(\dot{C}_{3}\right), 117\left(\dot{C}_{4}\right), 146.5\left(\dot{C}_{5}\right) \\
146.7\left(\dot{C}_{2}\right), 146.5\left(\mathrm{C}_{4}\right), 146.7 \\
\left(\mathrm{C}_{10}\right), 127.4\left(\mathrm{C}_{6} \text { and } \mathrm{C}_{\alpha}\right), 127.8 \\
\left(\mathrm{C}_{7}, \mathrm{C}_{\beta}\right), 130.5\left(\mathrm{C}_{8}, \mathrm{C}_{9}\right), 146.0 \\
\left(\mathrm{C}_{10}\right), 146.5\left(\mathrm{C}_{4}\right), 152.4\left(\mathrm{C}_{2}\right) \\
186.9(\mathrm{C}=\mathrm{O})\end{array}$ \\
\hline 6 & $\begin{array}{c}4.33\left(1 \mathrm{H}, \mathrm{m}_{1} \mathrm{C}_{2 \text { epoxide }}\right), 4.993- \\
4.997\left(1 \mathrm{H}, \mathrm{d}, \mathrm{C}_{3 \text { epoxide }}\right), 6.53\left(1 \mathrm{H}, \mathrm{s}, \mathrm{OH}_{\text {phenolic }}\right) \\
\text { 7.06-7.41(4H,m,Ar-H), } 7.69-7.71 \\
\left(1 \mathrm{H}, \mathrm{d}, \mathrm{C}_{8}\right), 7.41-7.43\left(1 \mathrm{H}, \mathrm{t}, \mathrm{C}_{7}\right), 7.88- \\
7.90\left(1 \mathrm{H}, \mathrm{t}, \mathrm{C}_{6}\right), 8.11-8.13\left(1 \mathrm{H}, \mathrm{d}, \mathrm{C}_{5}\right) \\
8.68\left(1 \mathrm{H}, \mathrm{s}, \mathrm{C}_{4}\right)\end{array}$ & $\begin{array}{c}58.55\left(\dot{C}_{2} \text { epoxide }\right), 57.83\left(\dot{C}_{3}\right. \\
\text { epoxide }), 148.2\left(\dot{C}_{4} \text { benzene }\right), 137\left(\mathrm{C}_{1}\right. \\
\text { benzene }), 122.49\left(\mathrm{C}_{3}, \mathrm{C}_{5} \text { benzene }\right), \\
135\left(\mathrm{C}_{2}, \mathrm{C}_{6} \text { benzene }\right), 127.1\left(\mathrm{C}_{7}\right), \\
127.8\left(\mathrm{C}_{5}\right), 128\left(\mathrm{C}_{6}\right), 129.6\left(\mathrm{C}_{8}\right), \\
129.3\left(\mathrm{C}_{9}\right), 147.0\left(\mathrm{C}_{4}\right), 149.3 \\
\left(\mathrm{C}_{10}\right), 150.0\left(\mathrm{C}_{2}\right), 193.53(\mathrm{C}=\mathrm{O}) .\end{array}$ \\
\hline
\end{tabular}




\section{REFERENCES}

1) M.M.Alam; D.P.Sarkar; O.Alam; A.Husain; A.Marella;A.Akhtar; M.S.Zaman, andS.Khanna,; ActaPoloniaePharmaceutica (Drug Research), 68(2), 231-236 (2011).

2) K.R.Gupta, A.Gupta, S.Paul and P.L.Kachrav, Indian J Chem., 1998, 37B, 1211.

3) M.M.Alam;D.P.Sarkar;; A.Husain;A.Marella;;M.Shaquiquzzaman; M.Akhter; M.Shaharyar; O.Alam and F.Azam; J. Serb. Chem. Soc. 76 (12) 1617-1626 (2011).

4) H.Kondo, F.Sakamoto, K.Kawakami and G.Tsukamoto; J. Med. Chem., 1988, 31, pp. 221-225.

5) W.R.Baker, S.Cai, M.Dimitroff, L.Fang, and J.H.Therricn,J. Med.Chem., 2004, 47, pp. 4693-4709.

6) A.A.Alhaider,M.A.Abdelkader, E.J.Lien,J.Med.Chem., 1985, 28 (10), pp.1394-1398

7) S.SakharamBorhade, Int. J. of Pharm. And Life Sci. (IJPLS), 3(1), 2012, 1344-1350.

8) E. Lukevics, J. Sega, A. Zablotskayn and S. German; Molecules, 1977, 2, 180 .

9) V. Mulwad, and M. Lohav, Indian J. Chem., 2003, 42B, 1973.

10) D.L. Dreyer, M.V.Pjckering, P. Cohan, Phytochemistry, 11, 1972, 705713.

11) L. Singer, N. P. Kong, J. Amer. Chem. Soci., 88(1960), 5213-5219.

12) S. Levy, S. J. Azoulay, J. Cardiovascular electrophysiology, 1994, 5, 653-636.

13) A.I. Vogel, "A Texet book of practical organic chemistry" $3^{\text {rd }}$ Ed., Longman, New Impression, 1972, page 653.

14) M.O. Conn, B. Narine, B. Tarmowski, J. Chem. Soc. Perkin Trans.1, 1520 (1981).

15) S. Dara, A. Ghatle, A. Rahatgaonkar, M. Chorghade, P. M.S. Chauhan and K. Srivastava, Indian J. Chem., 48B, (2004), 1780-1793.

16) O.T. Al-Obuidy, (2005) "Reaction of some alph-beta-unsaturated carbonyl compounds with a number of ketones", M.Sc. Thesis, University of Mosul, Mosul, Iraq.

17) E. El-Bandary and F.A. Badria, Pharm. Med.Chem., 333, (2000), 99103.

18) E.B. Kreinared, Z. Aizenshat, J. Org.Chem., 58, 6103 (1993).

19) S.Y. Hassan, Molecules (2013), 18, 2683-2711.

20) V. Nadaraj and S. Thamarai, J.Chem.Pharm.Res., 2012, 4(6), 28502853.

21) H. Junjappa, U. Kumar, C. Venkatesh, and P.K. Mahata, J. Org. Chem., 68, 2003, 3966.

22) M. Matsugi, F. Tabusa and J. Minamikawa, J. Tetrahedron Lett. 41, $2000,8523$.

23) V. Ramana, and C. Wentrup, J. Chem. Soc., Perkin Trans I, 1998, 2583.

24) A. Srivastava, R.M. Singh, Indian J. Chem.,44B, (2005), 1868. 